\title{
REVIEW: EFFECTS OF WOOD QUALITY AND REFINING PROCESS ON TMP PULP AND PAPER QUALITY
}

\author{
Bin Li, ${ }^{\mathrm{a}, *}$ Haiming Li, ${ }^{\mathrm{a}, \mathrm{b}}$ Quanqing Zha, ${ }^{\mathrm{a}}$ Rohan Bandekar, ${ }^{\mathrm{a}}$ Ahmed Alsaggaf, and \\ Yonghao $\mathrm{Ni}^{\mathrm{a}}$
}

\begin{abstract}
For the thermomechanical pulping (TMP) process both wood chip quality and the refining process have important effects on the resulting pulp and paper quality. Properties of wood raw material give a framework for final pulp properties. During TMP refining the specific energy consumption and refining intensity strongly impact fibre and pulp qualities. Increasing specific energy consumption benefits the development of fibres and improves their properties. However, high intensity refining tends to shorten the fibres and produces more fines content when compared with low intensity refining. This review focuses on the influence of key variables of chip qualities and the refining process on TMP pulp and paper qualities.
\end{abstract}

Keywords: Thermomechanical pulp; Pulp quality; Black spruce; Balsam fir; Basic density; Specific energy; Refining intensity

Contact information: a: Department of Chemical Engineering and Limerick Pulp and Paper Centre, University of New Brunswick, P.O. Box 4400, Fredericton, NB, E3B 5A3, Canada; b: Liaoning Key Laboratory of Pulp and Paper Engineering, Dalian Polytechnic University, Dalian 116034, China;

*Corresponding author: binli@unb.ca

\section{INTRODUCTION}

The thermomechanical pulping (TMP) process, in common with many other industrial processes, has high requirements for stability (Strand 1995; Wood 2001; Lundqvist et al. 2003; Sikter et al. 2007, 2008). Outcomes from the process are determined by two groups of parameters: 1) those from wood chips, and 2) those from the refining operation.

The quality of chips, including the wood species, has a strong influence on the process and end-product properties (Wood 1996, 2000; Lundqvist et al. 2003; Persson et al. 2005). Thus, a better understanding of the effect of chip qualities and refining process parameters is necessary to improve the control of the TMP pulping (e.g. less fluctuation, more productivity) and the properties of the resultant paper products. In Eastern Canada, the main wood species used for TMP production are black spruce (Picea mariana (Mill.) B.S.P.) and balsam fir (Abies balsamea (L.) (Mill.)) (Li et al. 2005; Dai et al. 2011a, 2011b).

The present review will focus on the effect of key wood chip qualities (wood species of black spruce and balsam fir, and basic density), and refining parameters (specific energy and refining intensity) on the resulting TMP pulp qualities. 


\section{EFFECT OF KEY WOOD CHIP QUALITIES}

The uniformity of pulp and the productivity of a pulp mill are influenced by many factors, but wood chip qualities, such as wood species, basic density, moisture content, seasonal variation, chip size, and bark content, can be important parameters. Even under normal operating conditions, some of these variations can be in the range of $10 \%$ to $15 \%$ (Varhimo and Tuovinen 1999a). It has been accepted that the properties of wood affect thermomechanical pulping in two principal ways (Tyrvainen 1995): 1) the wood species used; and 2) variations in wood basic density and moisture content, which causes variations in the refining consistency, thus, affecting the pulp uniformity and energy consumption. The effect of chip moisture could be minimized during chip washing; therefore, the influence of wood species and basic density will be the focus in this review.

\section{Wood Species}

The nature of fibres in a wood species determines the primary characteristics of pulp quality (Jackson 1998; Hoglund and Wilhelmsson 1993). Spruce is generally regarded worldwide as the benchmark wood species for TMP. The superiority of spruce has been attributed to its favourable fibre properties (fibre length, fibre coarseness, and fibre wall structure), low extractives content, high wood density, and high brightness of the wood, producing TMP with good strength, optical, and surface properties. In Eastern Canada, Balsam fir is usually mixed with spruces. Generally, some pulp properties e.g., tensile index and brightness, of balsam firs are slightly inferior to those of spruce TMP (Varhimo and Tuovinen 1999b). Some typical properties of black spruce and balsam fir, as well as their resulting TMP properties at the freeness level of $100 \mathrm{~mL}$, are given in Table 1.

Table 1. Wood Chip Properties of Black Spruce and Balsam Fir and Their Resulting TMP Properties at the Freeness Level of $100 \mathrm{~mL}^{*}$

\begin{tabular}{|l|c|c|c|c|}
\hline \multirow{2}{*}{ Quality parameters } & \multicolumn{2}{|c|}{ Black spruce } & \multicolumn{2}{c|}{ Balsam fir } \\
\cline { 2 - 5 } & Range & Mean (SD) & Range & Mean (SD) \\
\hline Chip density $\left(\mathrm{kg} / \mathrm{m}^{3}\right.$, raw material) & $395-415$ & $396(21)$ & $298-336$ & $318(13)$ \\
\hline Virgin fiber length $(\mathrm{mm}$, length weighted) & $2.76-3.09$ & $2.95(0.15)$ & $2.64-3.29$ & $2.87(0.21)$ \\
\hline Specific energy (MJ/kg) & $10.6-12.1$ & $11.5(0.67)$ & $7.7-10.5$ & $8.9(1.01)$ \\
\hline R48 fraction (\%) & $60.2-62.4$ & $61.2(0.91)$ & $56.0-62.4$ & $58.7(1.83)$ \\
\hline Length weighted mean fiber length $(\mathrm{mm})$ & $1.73-1.96$ & $1.83(0.10)$ & $1.44-1.70$ & $1.56(0.08)$ \\
\hline Rejects $\%$ od Pulp) & $0.2-0.6$ & $0.3(0.19)$ & $0.4-3.5$ & $1.8(1.12)$ \\
\hline Apparent sheet density $\left(\mathrm{kg} / \mathrm{m}^{3}\right)$ & $345-374$ & $361(14)$ & $294-330$ & $331(12)$ \\
\hline Tensile index $\left(\mathrm{N} \cdot \mathrm{m}^{2} \mathrm{~g}\right)$ & $48-49$ & $48.5(0.58)$ & $37-45$ & $40(2.35)$ \\
\hline Tear index $\left(\mathrm{mN} \cdot \mathrm{m}^{2} / \mathrm{g}\right)$ & $7.7-9.4$ & $8.6(0.70)$ & $7.4-8.9$ & $8.1(0.52)$ \\
\hline Burst index $\left(\mathrm{kPa} \cdot \mathrm{m}^{2} / \mathrm{g}\right)$ & $3.0-3.3$ & $3.2(0.13)$ & $2.2-2.9$ & $2.5(0.21)$ \\
\hline Brightness $(\%)$ & $55-58$ & $56(1.41)$ & $54-59$ & $57(1.42)$ \\
\hline Light scattering coefficient $\left(\mathrm{cm}^{2} / \mathrm{g}\right)$ & $572-590$ & $580(7.8)$ & $642-676$ & $656(14)$ \\
\hline * The original data was from Johal et al. $(2006)$ & & & \\
SD: Standard Deviation & & & & \\
\hline
\end{tabular}

It has been known that, at a given freeness, balsam fir requires noticeably less refining energy than black spruce. As shown in Table 1, the specific energy consumption 
is $7.7-10.5 \mathrm{MJ} / \mathrm{kg}$ for balsam fir at the freeness level of $100 \mathrm{~mL}$, while it is 10.6 to 12.1 $\mathrm{MJ} / \mathrm{kg}$ for back spruce at the same freeness. In fact, balsam fir produced much more fines than black spruce did, for a given refining energy (Lanouette and Law 2007). It is well known that the amount of fines in mechanical pulps is the determining factor affecting freeness. The average fibre length for pulps of balsam fir was substantially lower than that for the black spruce counterparts; for example, Johal et al. (2006) reported that the length weighted average fibre length is 1.44 to $1.70 \mathrm{~mm}$ for balsam fir, and 1.73 to 1.96 $\mathrm{mm}$ for black spruce at a given freeness of $100 \mathrm{~mL}$ CSF (Table 1). By contrast, the fibres in balsam fir wood are only about $10 \%$ shorter than those of black spruce (Xu et al. 2011).

Table 1 also showed that at a given freeness, balsam fir TMP pulp had signifycantly lower tensile index $(37-45 \mathrm{~N} \cdot \mathrm{m} / \mathrm{g})$ than that from black spruce $(48-49 \mathrm{~N} \cdot \mathrm{m} / \mathrm{g})$. Similar results were reported by Lanouette and Law (2007) as well. The above is in agreement with the fact that the sheet density of balsam fir TMP is lower than that of the spruce TMP. Generally, black spruce gave higher tensile index than balsam fir despite the fact that the latter had higher fines content at a given level of freeness.

In agreement with the fact that balsam fir TMP has more fines than the spruce TMP, the scattering coefficient of balsam fir TMP is higher than that of the spruce TMP. As given in Table 1, the light scattering coefficient is 642 to $675 \mathrm{~cm}^{2} / \mathrm{g}$ for balsam fir and 572 to $590 \mathrm{~cm}^{2} / \mathrm{g}$ for black spruce at the freeness level of $100 \mathrm{~mL}$. In general, the pulp scattering coefficient is greatly influenced by the quantity and quality of fines. Miles and Karnis (1993) reported that at the same amount of fines content and specific surface area, the scattering coefficient of balsam fir was higher than that of black spruce. The differences in the scattering coefficient between spruces and balsam fir TMP have been postulated most likely to be due to the lower wall thickness of balsam fir compared to spruces (Lecourt et al. 2003). Braaten (1997) has found a strong relationship between light scattering coefficient and fiber wall thickness: light scattering coefficient decreases with the increase of fiber wall thickness.

In a number of mills in Eastern Canada, balsam fir and spruce chips are co-refined in varying mixtures in the production of TMP. It was reported that increasing the balsam fir amount from $0 \%$ to $66.67 \%$ in the spruce furnish did not noticeably reduce the energy requirements to a given freeness, whereas when the balsam fir content increased from $66.67 \%$ to $100 \%$, the energy consumption decreased significantly (Johal et al. 2006). On the other hand, when increasing the proportion of black spruce in a furnish blend with balsam fir, both the fibre length and the tensile index at CSF of $100 \mathrm{~mL}$ increased with increasing specific energy (at the same CSF), but the light scattering coefficient could decrease with increasing the specific energy (Omholt et al. 2009).

\section{Basic Density}

The density of wood varies widely in different species, in different individuals, and even in different positions of the same tree. The greater the proportion of cell wall, the greater the density; consequently latewood has a higher density than earlywood, and the greater the proportion of latewood, the denser the wood as a whole. Woods composed largely of thick-walled, narrow-lumen fibres are always dense and heavy (Record 1919).

In one study it was reported that spruce growing in the northern hemisphere has a wood density of around $415 \mathrm{~kg} / \mathrm{m}^{3}$, while the density of balsam fir is around $340 \mathrm{~kg} / \mathrm{m}^{3}$

Li et al. (2011). "Effect of key variables on TMP quality," BioResources 6(3), 3569-3584. 3571 
(Klemm 1958). In another study (Johal et al. 2006), the wood chip density for black, red, and white spruce was reported in the range of 317 to $406 \mathrm{~kg} / \mathrm{m}^{3}$, and balsam fir was in the range of 298 to $336 \mathrm{~kg} / \mathrm{m}^{3}$. Most recently, Xu et al. (2011) reported that spruce in Eastern Canada has a wood density of 534 to $587 \mathrm{~kg} / \mathrm{m}^{3}$ and balsam fir has a wood density of 379 to $443 \mathrm{~kg} / \mathrm{m}^{3}$.

In addition to wood species, wood basic density could also be affected by tree age, seasonal variation, storage, latitude, altitude, etc. Brill (1985) found that spruce from northern Norway have a significantly lower basic density than their southern cousins. Tyrvainen (1995) reported that for Norway spruce, the basic density of mature wood with $16.9 \%$ juvenile wood content is $425 \mathrm{~kg} / \mathrm{m}^{3}$, whereas the density of first-thinning wood with $58.3 \%$ juvenile wood content is $396 \mathrm{~kg} / \mathrm{m}^{3}$. Atack et al. (1985) found that the density of balsam fir killed by budworm after 3 years is approximately 30 to $40 \%$ less than that of sound wood.

A difference in basic density could result in variations in chip bulk density, which may lead to production rate changes and changes in specific energy. This type of variation could potentially lead to short-term variations in the pulp properties. As shown in Table 1, at a given freeness of $100 \mathrm{~mL}$ CSF, low chip density balsam fir requires considerably less energy $(8.94 \mathrm{MJ} / \mathrm{kg})$ than high-density spruces $(12.01 \mathrm{MJ} / \mathrm{kg})$. At most TMP operations that target a pulp freeness, this $34 \%$ variation in species explains a major source of production variability and has significant cost implications. However, the influence of wood density on refining energy consumption in TMP pulping is not always conclusive, and wood density is an indicator but not a predictor of energy consumption (Miles and Karnis 1995). Even for a given species with the same wood density, energy consumption to a given freeness can vary as much as 30\% (Miles and Karnis 1993). In contrast, Tyrvainen (1995), Corson (1997), and Heikkurinen et al. (1999) reported no differences in specific energy consumption to a constant CSF between thinning wood (lower density) and sawmill chips (higher density).

Within the EuroFiber project based on the research of the effect of Norway spruce quality on TMP properties, consistent results from laboratory (Lecourt et al. 2003), pilot plant (Fuglem et al. 2003), and mill trial studies (Persson et al. 2003) were found that pulps produced from the longer fiber/higher density wood had higher tear index, lower scattering coefficient, and lower energy consumption, while pulps from the shorter fiber/lower density wood had higher scattering coefficient, but lower tear index and higher energy consumption. In particular, from the pilot study, Fuglem et al. (2003) concluded that the tear index, light scattering coefficient, and Parker Print Surf (PPS) can be described as functions of virgin fibre length and wood basic density, and their empirical relations are given in Equations 1, 2, and 3, respectively. When the functions were presented at three different basic densities of $332 \mathrm{~kg} / \mathrm{m}^{3}, 380 \mathrm{~kg} / \mathrm{m}^{3}$, and $435 \mathrm{~kg} / \mathrm{m}^{3}$, respectively, in the same range of $2.0 \mathrm{~mm}$ to $3.4 \mathrm{~mm}$ virgin fibre length, they found that tear strength is more dependent on the wood basic density than on the fibre length, while light scattering and PPS are strongly influenced by both basic density and fibre length.

$$
\begin{aligned}
& \text { Tear }=0.76+0.386 \cdot \text { Fibre length }+0.016 \cdot \text { Basic density } \quad \mathrm{R}^{2}=0.66 \\
& \text { Light scat }=74.28-3.80 \cdot \text { Fibre length }-0.033 \cdot \text { Basic density } \quad \mathrm{R}^{2}=0.70
\end{aligned}
$$




$$
P P S=0.68+0.331 \cdot \text { Fibre length }+0.004 \cdot \text { Basic density } \quad \mathrm{R}^{2}=0.85
$$

However, it should be emphasized that the basic density itself is not an explanation for paper properties; rather, it reflects a set of basic fibre characteristics; e.g. fiber perimeter and wall thickness accounted for much, but not all, of the wood density impact (Corson 1997). Thus, a decrease in basic density tends to increase the sheet density, air resistance, tensile index, and scattering coefficient, while tear index decreases. An increased tear index is observed when fiber wall thickness increases, accompanied by a decrease of perimeter (Lecourt et al. 2003). Corson $(1984 ; 1991)$ found that relative to wood type, basic wood density had only a small influence on refining energy demand and the subsequent pulp properties of the different wood sub-samples, when compared on the basis of freeness, sheet density, and tensile index. The separation of wood into corewood and slabwood divides it on the basis of both basic wood density and tracheid length, and basic wood density was found to be of secondary importance to wood age; this finding implied that it was tracheid length (or some factor associated with it, or wood age) that would control the pulping performance. A poor correlation was also found between the basic density and TMP properties in other detailed studies (Montmorency 1965; Brill 1985).

\section{EFFECT OF TMP PROCESS}

Besides the quality of raw materials, refining operation and the resultant pulp quality are strongly dependent on the TMP process (see Fig. 1). In TMP refining, individual fibres are separated from their ordered configuration in wood by mechanical forces and then substantially developed to meet their papermaking properties (Corson 2002; Gorski et al. 2010). It is important that fibre cutting is minimized to produce pulp with good strength qualities.

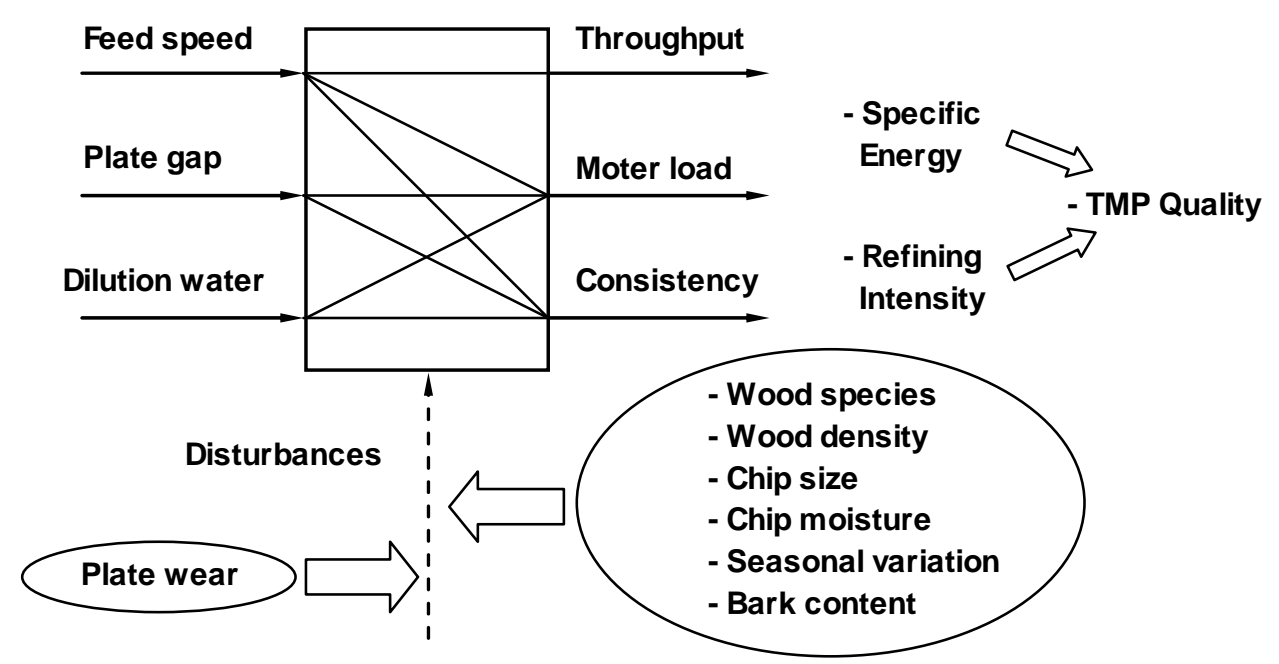

Fig. 1. Control strategies of a chip refiner (Schematic diagram) 
The ideal refining action will remove the middle lamella and outer layers from the fibre wall to produce fibres and fines with good bonding potential. Typical controlled and manipulated variables in refining are illustrated in Fig. 1. Wearing of refiner plates and variations in raw material are the two important types of disturbances in a refining system. For obtaining a uniform pulp quality, the three input variables of feeder speed, plate position, and dilution flow, can be used to control the three output variables of throughput, motor load, and refining consistency, to minimize these variations. In this multivariable system, although these parameters are more or less interrelated, pulp quality is mainly a function of two variables: specific energy and refining intensity (Miles and May 1993; Roche et al. 1996; Illikainen 2008).

\section{Specific Energy}

How much energy is put into a given amount of pulp is defined as the specific energy consumption. In refining, it is determined as energy per unit mass of pulp, generally calculated from refining power and production rate of pulp (Eq. 4) for a given refiner (Miles and May 1990).

$$
\text { Specific energy = motor load } / \text { throughput }
$$

Energy applied to the fibres is expended in two stages during refining: firstly, energy consumed in defibration, and secondly, energy expended in additional fibre modifications (fibrillation, collapse, and others), to meet pulp property requirements. The defibration/separation energy is consumed in three ways: in plastic work during the deformation of the specimen; in the breakage of fibres across their long axes; and in the creation of new fibre surfaces (Koran 1981). The fibre separation step was concluded to be crucial in determining how efficiently energy is consumed in the subsequent refining stages (Heikkurinen et al. 1993). If the fibre separation step is inefficient, the applied energy will be used up in completing the fibre separation; thus the energy is used less effectively for further development of the fibers (Gorski et al. 2010). However, most of the energy is consumed in the fibrillation stage (Sabourin et al. 2002). In this stage the middle lamellae, primary wall, and S1 are removed, and parts of the S2-layer are stripped off. Material that is only partly removed from the fibre surface (outer fibrillation) will give the long fibres a large specific surface area, which is favourable for fibre bonding. The reduction of the fibre wall thickness will reduce the fibres' rigidity, improve bonding, and produce fibrillar fines with large specific surface area (Reme and Helle 2001).

In the chip refining process, the quality of the pulp produced from a given wood supply depends, to a large extent, upon the applied specific energy. The more the applied energy is consumed for refining pulp, the greater the changes in fiber and pulp properties. Increasing specific energy decreases fibre length (Law 2000), reduces fibre coarseness of long fibre fraction, and fibres become more flexible (Karnis 1994; Rusu et al. 2011). Fibres are peeled, collapsed, cell wall thickness decreases (Corson and Ekstam 1994), and cell wall delamination/internal fibrillation increases (Fernando and Daniel 2010; Rusu et al. 2011). On the other hand, the fine content and specific surface area of fines increases with the increase in specific energy (Chagaev and Zou 2007). Consequently,

Li et al. (2011). "Effect of key variables on TMP quality," BioResources 6(3), 3569-3584. 3574 
freeness (Corson 1989), shive content (Law 2000), pulp linting propensity index (PLPI) (Miles et al. 1990), and bulk decrease, whereas scattering coefficient and opacity increase (Stationwala et al. 1996). Burst and tensile indices generally increase (Stationwala et al. 1994), but the tear index may increase or decrease, depending on the relative rates of change of fibre length reduction and development of fibre specific surface during the pulping operation (Miles and May 1990, 1993). The rate at which pulp properties change with increasing specific energy may be a strong function of the particular process conditions (Stationwala et al. 1979). It has been known that more energy on the first stage results in higher freeness drop, while more energy on the second stage results in shorter fibres (Sui et al. 1998).

Another important factor is the energy consumption distribution in the refiner disc gap. Miles and May (1990) assumed that the applied energy is mainly consumed in the refining zone, while the energy consumption in the inner parts is small. On the other hand, it was reported that the energy consumption before the maximum temperature inside the refiner is as large as the energy consumption in the outer parts of the refiner (Härkönen and Tienvieri 2001); the energy is mainly consumed in fiber-to-fiber refining by shearing of compressed pulp in the inner parts of the refiner (Illikainen et al. 2007a), while the contacts between segment surface and pulp became more important in the outer parts of refiner (Härkönen et al. 2003; Illikainen 2008). Measurements of shear forces in a refiner disc gap in a laboratory refiner (Gradin et al. 1999) and a commercial refiner (Backlund et al. 2003) proposed energy consumption to increase along the disc radius. The largest energy consumption is at the segment periphery, and the energy distribution differs along the disc segments (Muhić et al. 2010a).

Some studies indicated that the energy distribution depends not only on the segment geometry used in a refiner, but also on the refiner stage. In the first stage refiner more power was consumed in the inner parts of the refiner compared to the second stage refiner (Illikainen et al. 2007b). At the inlet of the disc gap of primary refiner, there is an intensive mixing zone where pulp properties start to change. When pulp reaches the narrow disc gap, freeness and fiber length are reduced, while tensile and tear properties are being developed (Härkönen et al. 2003). In the secondary refiner inlet, there is a somewhat weaker mixing zone than in the primary refiner where fibers continue to develop as the pulp proceeds through this gap. The mechanisms are different in the second stage refiner due to the fact that the feed is now pulp, instead of wood chips, thus the energy distribution is also different (Illikainen 2008). A better pulp quality was reported when at least $60 \%$ of the total energy was applied to the first refining stage (Lanouette et al. 1994; Broderick et al. 1996).

Although experience has shown that the key to a longer, more developed fibre is to put more energy into the pulp, there have been significant research efforts worldwide to reduce the energy consumption in mechanical pulping. This can be done by softening the fibre by heat (Fernando and Daniel 2008; Muhić et al. 2010b), chemicals (Hill et al. 2009; Johansson et al. 2011), or enzyme pretreatment (Meyer et al. 2009; Sabourin et al. 2009), compressive pretreatment (Kure et al. 1999; Gorski et al. 2010), or by reducing the refining intensity (Miles and May 1990; McDonald et al. 2004; Huhtanen et al. 2009; Muhić et al. 2010a). 


\section{Refining Intensity}

The concept of refining intensity was proposed for thermomechanical pulp refining by Miles and May (1990). Refining intensity describes how rapidly energy is put into pulp, and it is defined as the specific energy delivered per bar impact. It is a function of cumulative forces applied on the fiber during its residence time in the refiner. With a constant specific energy, a reduced residence time leads to increased refining intensity. One must notice that there have been only a few empirical tests made concerning the residence time, and it is thus more appropriate to use refining intensity as a qualitative term to describe if the refining is harsh or gentle (Illikainen 2008). In general, low (gentle) intensity refining produces pulps of higher strength but lower opacity, while high (harsh) intensity refining produces pulps with lower strength but better printing properties (Stationwala et al. 1991a; Muhić et al. 2010a). Recently, another way of defining the refining intensity (Eq. 5), based on the flow conditions and thermo-dynamical state inside the refiner, was proposed (Huhtanen et al. 2004, 2009):

$$
I_{H \& H}=(60 \times P) /\left(n \times N_{b} \times t_{r}\right)
$$

The intensity is the power consumption for every bar crossing given that all fibres are moving through the refiner with a minimum residence time; $I_{H \& H}$ is the refining intensity, $P$ is the power consumption, $n$ is the rotational speed in rpm, $N_{b}$ is the number of bars, and $t_{r}$ is the minimum fibre residence time. The minimum fibre residence time is used to describe the flow phenomena inside the refiner. Equation 5 describes how the refining intensity can be altered by changing the power input, rotational speed, number of segment bars, and pulp consistency that would affect $t_{r}$. This theory could be a good tool to elucidate the refining segment role in chip refining as it considers the effect of segment design on steam and material flow (Muhić et al. 2010a). The key parameters that affect refining intensity are discussed below:

\section{1) Specific energy}

Increasing specific energy has two main effects: the plate gap is reduced and the energy per refiner bar impact is increased (Murton 1998). Therefore, increasing specific energy increases the refining intensity (Miles 1991; Huhtanen et al. 2009).

\section{2) Refining pressure/temperature}

Adjusting refiner differential pressure (discharge pressure minus feed pressure) over plate gap, from positive to negative pressure, decreases the residence time and increases the refining intensity (Miles and May 1990; Härkönen et al. 2003; Huhtanen et al. 2009). However, it also increases refiner thrust bearing load substantially (Lunan 1985); this can limit the large negative pressure differentials, while any change of pressure in the refiner will affect the temperature (Sikter et al. 2007). In the course of optimizing the refining process, it was found that improved energy efficiency was obtained at the same tensile index level when applying higher pressure (temperature) (Kure and Dahlqvist 1998; Muhić et al. 2010a). Higher temperature can have better softening effect on fibres, leading to easier initial fibre separation and fibrillation, although it may result in lower brightness. A lower plate gap can increase tensile index 
and light scattering coefficient at a given specific energy (Stationwala et al. 1991a; Muhić et al. 2010b). Also, the fiber length reduction caused by a higher intensity can be mitigated by increasing temperature (Kure et al. 2000; Huhtanen et al. 2009).

\section{3) Production rate}

Increasing the production rate, by decreasing the refiner plate gap and lowering the residence time, would cause an increase in the refining intensity (Stationwala et al. 1994; Strand et al. 1993; Härkönen and Tienvieri 1995, 2001). This influence appears to be more significant at low production rates (Murton and Corson 1997).

\section{4) Consistency}

When pulp consistency is increased, there is less water in the refining zone so that the centripetal force is reduced and more pulp will remain between the refiner plates; thus the residence time increases, causing the refining intensity and the specific refining power to decrease (Alami et al. 1997; Stationwala et al. 1991b; Huhtanen et al. 2009). For a given refiner, at a given rotational speed, the impulsion applied to each unit mass of fibre is dictated by its total mass and therefore is inversely proportional to the refining consistency (Miles and May 1990). The approach shown in pilot-plant trials with a constant total specific energy is to employ high intensity-low energy refining in the first stage, where the high-impact energy can efficiently break down the material and separate fibres (Stationwala et al. 1993; Miles et al. 1991). The second-stage refining is then carried out at a normal level of intensity to develop fibres with minimal damage. By this approach, pulp could be produced with improved printing properties but without loss in strength. A study has shown that a 7\% reduction in total specific energy could be achieved when the consistency in the primary refiner was reduced from $50 \%$ to $38 \%$ to obtain a pulp of $200 \mathrm{~mL}$ CSF in the discharge of secondary refiner (Alami et al. 1997). The energy reductions were obtained without adverse effect on pulp properties. However, the energy savings become smaller when the normal operating consistency level in the mill is already low and the final discharge freeness is less than $200 \mathrm{~mL}$ CSF (Alami et al. 1997).

\section{5) Rotational speed}

Another approach, based on the concept of high-intensity refining, is to increase the rotational speed. At a given consistency, the refining intensity is proportional to the square of the rotational speed (Miles and May 1990). Bar crossings per unit time are proportional to the speed, whereas the residence time is inversely proportional to the cube of the speed. Residence time then determines specific energy per bar impact and the energy application rate on the passing fibres during the refining. Stationwala et al. (1991b; 1994 ) found that pulp produced at high intensity $(1800 \mathrm{rpm})$ would require about $25 \%$ less energy than that produced at low intensity $(1200 \mathrm{rpm})$ to reach the same freeness, about 15 times lower shive content for the high intensity pulp, and at a given specific energy, the tensile strength would be $25 \%$ higher for the high intensity pulps. Based on the concept of low residence time, high steam pressure and high rotational speed, Kure and Dahlqvist (1998) determined the optimum process conditions that were beneficial for both specific energy consumption and fibre properties, and the process can produce more 
thin-walled fibres. Increasing the refining intensity by increasing rotational speed in the range 1800-2900 rpm increased the fraction of fibres with longitudinal splits in the fibre wall (Kure et al. 1999). These fibres will collapse easily and contribute to a denser, smoother sheet, thus an improved printing surface. Thin-walled fibres with high specific surface area also give higher light scattering (Kure et al. 2000).

\section{6) Plate pattern}

Last but not least, refining intensity could also be influenced by plate pattern, because any changes in the plate design could change pulp residence time in the refining zone, thus affecting the refining efficiency (Vuorio and Bergqvist 2001; Muhić et al. 2010a). In general, the refining intensity can be increased by using forward feed-type segment bars and grooves, which feed pulp and steam forward in the gap (Varhimo and Tuovinen 1999c). Thus the residence time of pulp is reduced, resulting in increased intensity of refining. Changing the refiner plate pattern from a fine to a coarse pattern can make the refining action harsher, and reduce the long fibre content (Murton 1998; Heikkurinen et al. 1991; Murton et al. 2002) and fibre wall thickness (Murton 1998; Murton et al. 2002). For a constant energy input, increasing the number of bars on the refiner plate will decrease the refining intensity (Miles and May 1990).

\section{CONCLUSIONS}

In the thermomechanical pulping (TMP) process, many factors affect fibre separation and refining processes and the resultant pulp qualities. On the one hand, wood chip quality is critical. Due to their different chemical composition and different fibre morphology, wood species have a great effect on the refining process and the quality of end products. Black spruce and balsam fir are the most popular species for producing TMP-based newsprint in Eastern Canada. Black spruce, which has higher basic density and longer fibre length, requires more energy at a given freeness compared to balsam fir, and it can produce TMP with significantly higher strength properties, while balsam fir with lower cell wall thickness can provide superior optical properties than black spruce. The basic density of black spruce is higher than that of balsam fir. Variations in wood chip basic density can result in instability of refining process, which may lead to variations of pulp properties. Therefore, one approach of improving TMP pulp properties is to have a consistent supply of wood species.

On the other hand, specific energy consumption and refining intensity play an important role in final TMP properties. More energy would result in more fully developed fibres, thus better pulp qualities. A higher refining intensity can decrease the fibre length, create more fines, and reduce long fibre fraction, whereas a lower intensity can defiberate fibres without fibre cutting. The most advanced control solutions use pulp quality measurements, such as the pulp freeness and the average fibre length (Varhimo and Tuovinen 1999a; Sikter et al. 2007), as feedback. However, the uniformity of the raw material may turn out to be the best way to control a refiner system. 


\section{ACKNOWLEDGEMENTS}

The financial support for this project was from an NSERC CRD grant of the Government of Canada.

\section{REFERENCES CITED}

Alami, R., Boileau, I., Harris, G., Lachaume, J., Karnis, A., Miles, K. B., and Roche, A. (1997). "Impact of refining intensity on energy reduction in commercial refiners: Effect of primary - stage consistency," Tappi J. 80(1), 185-193.

Atack, D., Fontebasso, J., and Stationwala, M. I. (1985). "The characterization and grinding of budworm killed balsam fir,” J. Pulp Pap. Sci. 11(1), 1-7.

Backlund, H.-O., Höglund, H., and Gradin, P. (2003) "Study of tangential forces and temperature profiles in commercial refiners," 2003 International Mechanical Pulping Conference, Quebec, Canada, 379-388.

Braaten, K. R. (1997) “The impact of geometry, fiber splitting and fibrillation on the light scattering coefficient," 1997 International Mechanical Pulping Conference, Stockholm, Sweden, June 9-13, 349-353.

Brill, J. W. (1985). "Effect of wood and chip quality on TMP properties," 1985 International Mechanical Pulping Conference, Proceedings, Stockholm, 153-161.

Broderick, G., Paris, J., and Valade, J. L. (1996) "Fiber development in chemimechanical pulp refining," Tappi J. 79(4), 193-201.

Chagaev, O., and Zou, X. (2007). "A new concept to characterize fibre development in refining and mechanical pulp quality for LWC and SC grades," Pulp Paper Canada 108(1), 50-56.

Corson, S. R. (1984). "Influence of wood quality characteristics on TMP and RMP from New Zealand-grown radiate pine," Appita J. 37(5), 400-408.

Corson, S. R. (1989). "Aspects of mechanical pulp fibre separation and development in a disc refiner," Paperi Ja Puu - Paper \& Timber 71(7), 801-814.

Corson, S. R. (1991). "Wood characteristics influence pine TMP quality," 1991 International Mechanical Pulping Conference, Atlanta, USA, June 2-5, 243-251.

Corson, S. R., and Ekstam, E. (1994). "Intensive refining of radiate pine fibre," Paperi Ja Puu - Paper \& Timber 76(5), 334-339.

Corson, S. R. (1997) "Tree and fiber selection for optimal TMP quality," 1997 International Mechanical Pulping Conference, Stockholm, Sweden, June 9-13, 231240.

Corson, S. R. (2002). "Process impacts on mechanical pulp fibre and sheet dimensions," Pulp Paper Canada 103(2), 20-27.

Dai, Z., Ni, Y., Court, G., and Li, Z. (2011a). "Mitigating pitch-related deposits at a TMP-based specialty paper mill," Tappi J. 10(3), 47-52.

Dai, Z., Court, G., Li, Z., and Ni, Y. (2011b) "Effect of polymers and metal ions on the behavior of pitch from a spruce TMP-based specialty paper mill based on DSC and confocal LSM analysis," BioResources 6(2), 1764-1772. 
Fernando, D., and Daniel, G. (2008). "Exploring scots pine fibre development mechanisms during TMP processing: Impact of cell wall ultrastructure (morphological and topochemical) on negative behaviour," Holzforschung 62: 597607.

Fernando, D., and Daniel, G., (2010) "Characterization of spruce thermomechanical pulps at the fiber cell wall level: A method for quantitatively assessing pulp fiber development using Simons' stain," Tappi J. 9(10), 47-55.

Fuglem, G., Sabourin, M., and Lundqvist, S. O. (2003). "Influence of spruce wood properties on thermomechanical pulping - Pilot scale results," 2003 International Mechanical Pulping Conference, Quebec, Canada, June 2-5, 75-82.

Gorski, D., Hill, J., Engstrand, P., and Johansson, L. (2010). "Review: Reduction of energy consumption in TMP refining through mechanical pre-treatment of wood chips," Nord Pulp Pap. Res. J. 25(2), 156-161.

Gradin, P. A., Johansson, O., Berg, J.-E., and Nyström, S. (1999) "Measurement of the power distribution in a single disc refiner," J. Pulp Pap. Sci. 25(11), 384-387.

Härkönen, E., and Tienvieri, T. (1995). "The influence of production rate on refining in a specific refiner," 1995 International Mechanical Pulping Conference, Montreal, Canada, 177-182.

Härkönen, E., and Tienvieri, T. (2001). "Energy savings in TMP pulping," 2001 International Mechanical Pulping Conference, Helsinki, Finland, 547-556.

Härkönen, E., Kortelainen, J., Virtanen, J., and Vuorio, P. (2003) "Fiber development in TMP main line,” 2003 International Mechanical Pulping Conference, Quebec, Canada, 171-178.

Heikkurinen, A., Vaarasalo, J., and Karin, A. (1993). "Effect of initial defiberization on the properties of refiner mechanical pulp," J. Pulp Paper Sci. 19(3), 119-124.

Heikkurinen, A., Lucander, M., and Sirviö, J., and Varhimo, A. (1999). "Effect of spruce wood and fiber properties on pulp quality under varying defibration conditions," 1999 International Mechanical Pulping Conference, Houston, May 24-26, 11-34.

Heikkurinen, A., Vaarasalo, J., and Karnis, A. (1991). "Effect of initial defiberization on the properties of refiner mechanical pulp," 1991 International Mechanical Pulping Conference, Minneapolis, June 2-5, 303-319.

Hill, J., Johansson, L., Sabourin, M., and Aichinger, J. (2009) "Enhancing fibre development at reduced energy consumption using TMP sub-process and targeted chemical application - pilot and commercial scale results," 2009 International Mechanical Pulping Conference, Sundsvall, Sweden, 36-45.

Hoglund, H., and Wilhelmsson, K. (1993). "The product must determine the choice of wood type in mechanical pulping," 1993 International Mechanical Pulping Conference, Oslo, Norway, June 15-17, 1-22.

Huhtanen, J.-P., Karvinen, R., Vikman, K., and Vuorio, P. (2004). "Theoretical background of new energy saving refiner segments design," Proceedings of PulPaper Conference, Energy and Carbon Management, Helsinki, Finland, 111-118. Huhtanen, J.-P., Karvinen, R., Vikman, K., and Vuorio, P. (2009). "Determination of freeness reduction by refining intensity definition based on fluid dynamical model," 2009 International Mechanical Pulping Conference, Sundsvall, Sweden, 209-212. 
Illikainen, M., Härkönen, E., and Niinimäki, J. (2007a). "Power consumption and fibre development in a TMP refiner plate gap: Comparison of unidirectional and standard refiner segments," 2007 International Mechanical Pulping Conference, Minneapolis, USA.

Illikainen, M., Härkönen, E., Ullmar, M., and Niinimäki, J. (2007b). "Power consumption distribution in a TMP refiner: comparison of the first and second stages," Tappi J. 6(9), 18-23.

Illikainen, M. (2008). "Mechanisms of thermomechanical pulp refining," Ph.D Thesis, University of Oulu, Finland.

Jackson, M. (1998). "The interaction of wood species and wood quality with the TMP process - A review," TAPPI Pulping Conference Proceedings, Montreal, 455-465.

Johal, S., Yuen, B., and Watson, P. (2006). "The effects of species on the thermomechanical pulping of balsam fir, black spruce, red spruce and white spruce," Pulp Paper Canada 107(7/8), 41-45.

Johansson, L., Hill, J., Gorski, D., and Axelsson, P. (2011) "Improvement of energy efficiency in TMP refining by selective wood disintegration and targeted application of chemicals," Nord Pulp Pap. Res. J. 26(1), 31-46.

Karnis, A. (1994). "The mechanism of fibre development in mechanical pulping," J. Pulp Pap. Sci. 20(10), J280-J288.

Klemm, K. H. (1958). Modern Methods of Mechanical Pulp Manufacture, Translation by Chinn, E. P.: Lockwood Trade Journal Co., Inc., New York, 11-26.

Koran, Z. (1981). "Energy consumption in mechanical fibre separation as a function of temperature," Pulp Paper Canada 82(6), 40-44.

Kure, K. A., and Dahlqvist, G. (1998). "Development of structural fibre properties in high intensity refining - Cross-sectional fibre dimensions are significantly changed in refining," Pulp Paper Canada 99(7), 59-63.

Kure, K. A., Dahlqvist, G., Sabourin, M. J., and Helle, T. (1999). “Development of spruce fibre properties by a combination of a pressurized compressive pretreatment and high intensity refining," 1999 International Mechanical Pulping Conference, Houston, USA, May 24-26, 427-433.

Kure, K. A., Sabourin, M. J., Dahlqvist, G., and Helle, T. (2000). “Adjusting refining intensity by changing refiner plate design and rotational speed - Effects on structural fiber properties," J. Pulp Pap. Sci. 26(10), 346-352.

Lanouette, R., Brokerick, G., and Valade, J. L. (1994). "L'Optimisation du raffinage par la modélisation statistique," Proceedings Conference Technologique Estivale, CPPA, Montreal, June 1-3.

Lanouette, R., and Law, K. N. (2007). "Effect of chip aging on the papermaking properties of TMP," PAPTAC 93 ${ }^{\text {rd }}$ Annual Meeting, Book C, 103-107.

Law, K. N. (2000). "Rethinking chip refining," Proceedings of $54^{\text {th }}$ Appita Annual Conference, Melbourne, Australia, 101-106.

Lecourt, M., Deleuze-Brézins, C., Fauchon, T., Themelin, A., Lundqist, S.-O., Grahn, T., Wilhelmsson, L., and Arlinger, J. (2003). "Modeling TMP fiber morphology and pulp properties from wood and forest data: the example of Norway spruce significant," 2003 International Mechanical Pulping Conference, Quebec, Canada, June 2-5, 67-74. 
Li, Z., Court, G., Belliveau, R., Crowell, M., Murphy, R., Gibson, A., Wader, M., Branch, B., and Ni, Y. (2005). "Using magnesium hydroxide $\left(\mathrm{Mg}(\mathrm{OH})_{2}\right)$ as the alkali source in peroxide bleaching at Irving paper," Pulp Paper Canada 106(6), 24-28.

Lunan, W. E., Miles, K. B., and May, W. D. (1985). "Effect of differential pressure on energy consumption in thermomechanical pulping," J. Pulp Pap. Sci. 11(5), 129-135.

Lundqvist, S.-O., Ekenstedt, F., Grahn, T., Hedenberg, Ö., Olsson, L., and Wilhelmsson, L. (2003). "Selective use of European resources of spruce fibers for improved pulp and paper quality," 2003 International Mechanical Pulping Conference, Quebec, Canada, June 2-5, 59-66.

McDonald, D., Miles, K., and Amiri, R. (2004). "The nature of the mechanical pulping process," Pulp Paper Canada 105(8), 27-32.

Meyer, V., Lecourt, M., and Petit-Conil, M. (2009). "Bio-TMP process to save energy: Comparison of enzymes efficiency," 2009 International Mechanical Pulping Conference, Sundsvall, Sweden, 230-233.

Miles, K. B. (1991). "A simplified method for calculating the residence time and refining intensity in a chip refiner," Paperi Ja Puu-Paper and Timber 73(9), 852-857.

Miles, K. B., and Karnis, A. (1993). "Energy consumption in mechanical pulping the effect of wood supply,” Pointe Claire, QC: Paprican, PPR 1015.

Miles, K. B., and Karnis, A. (1995). "Wood characteristics and energy consumption in refiner pulps," J. Pulp Pap. Sci. 21(11), 383-389.

Miles, K. B., and May, W. D. (1990). “The flow of pulp in chip refiners," J. Pulp Pap. Sci. 16(2), 63-72.

Miles, K. B., and May, W. D. (1993). "Predicting the performance of a chip refiner: A constitutive approach,” J. Pulp Pap. Sci. 19(6), 268-274.

Miles, K. B., May, W. D., and Karnis, A. (1990). "Refining intensity, energy consumption and pulp properties in two-stage chip refining," Preprints TAPPI Pulping Conference, Toronto, 14-17.

Miles, K. B., May, W. D., and Karnis, A. (1991). "Refining intensity, energy consumption, and pulp quality in two-stage chip refining," Tappi J. 74(3), 221-230.

Muhić, D., Huhtanen, J.-P., Sundström, L., Sandberg, C., Ullmar, M., Petteri, V., and Engstrand, P. (2010a). "Energy efficiency in double disc refining - Influence of intensity by segment design," $7^{\text {th }}$ International Seminar on Fundamental Mechanical Pulp Research, June 21-23, Nanjing, China, 109-117.

Muhić, D., Sundström, L., Sandberg, C., Ullmar, M., and Engstrand, P. (2010b) "Influence of temperature on energy efficiency in double disc chip refining," Nord Pulp Pap. Res. J. 25(4), 420-427.

Montmorency, de, W. H. (1965). "The relationship of wood characteristics to mechanical pulping," Pulp and Paper Magazine of Canada, June, 325-347.

Murton, K. D. (1998). "Refining intensity impact on slabwood and thinnings TMP," Appita J. 51(6), 433-440.

Murton, K. D., and Corson, S. R. (1997). "Production rate effect on TMP pulp quality and energy consumption," J. Pulp Pap. Sci. 23(8), J411-J416.

Murton, K. D., Corson, S. R., and Duffy, G. G. (2002). "Effect of refining intensity on slabwood and thinnings TMP fibres," Appita J. 55(2), 155-161. 
Omholt, I., Miles, K. B., Stacey, M., and Dranfield, D. (2009). "TMP from blends of wood species - implications for control," PAPTAC 95 ${ }^{\text {th }}$ Annual Meeting, 75-80.

Persson, E., Engstrand, P., Karlsson, L., Nilsson, F., and Wahlgren, M. (2003). "Utilization of the natural variation in wood properties - A comparison between pilot plant and mill scale trials," 2003 International Mechanical Pulping Conference, Quebec, Canada, June 2-5, 83-90.

Persson, E., Sundström, L., and Xu, E. (2005) "Differences between Norway spruce and Scots pine with respect to refining response and content of extractives," 2005 International Mechanical Pulping Conference, Oslo, Norway, 143-148.

Record, S. J. (1919). Economic Woods of the United States. The Second Edition, John Wiley \& Sons, Inc., New York, 49-50.

Reme, P. A., and Helle, T. (2001). "Quantitative assessment of mechanical fibre dimensions during defibration and fibre development," J. Pulp Pap. Sci. 27(1), 1-7.

Roche, A., Owen, J., Miles, K. B., and Harrison, R. (1996). "A practical approach to the control of TMP refiners," Control systems'96 Preprints, 129-135.

Rusu, M., Mörseberg, K., Gregersen, Ø., Yamakawa, A., and Liukkonen, S. (2011) "Relation between fibre flexibility and cross-sectional properties," BioRessources 6(1), 641-655.

Sabourin, M., Vaughn, J., Wiseman, N., Cort, J. B. and Galatti, P. (2002). "Mill scale results on TMP pulping of southern pine with pressurized chip pretreatment," Pulp Paper Canada 103(6), 37-42.

Sabourin, M., Mäentausta, O., Räsänen, K., and Braeuer, P. (2009). “Targeting enzyme formulations at selective wood components for optimized thermomechanical pulping of spruce," 2009 International Mechanical Pulping Conference, Sundsvall, Sweden, 50-58.

Sikter, D., Karlström, A., Engstrand, P., and Czmaidalka, J. (2007). "Using the refining zone temperature profile for quality control," 2007 International Mechanical Pulping Conference, Minneapolis, Minnesota, USA, May 7-9.

Sikter, D., Karlström, A., Sandberg, C., and Engstrand, P. (2008). "Economic perspectives on quality control in TMP refining processes," Nord Pulp Pap. Res. J. 23(3), 305-314.

Stationwala, M. I., Atack, D., Wood, J. R., Wild, D. J., and Karnis, A. (1979). "The effect of control variables on refining zone conditions and pulp properties," 1979 International Mechanical Pulping Conference, Toronto, 93-109.

Stationwala, M. I., Atack, D., Wood, J. R., Wild, D. J., and Karnis, A. (1991a). "The effect of control variables on refining zone conditions and pulp properties," Paperi Ja Puu-Paper and Timber 73(1), 62-69.

Stationwala, M. I., Miles, K. B., and Karnis, A. (1991b). "The effect of first stage refining conditions on pulp properties and energy consumption," 1991 International Mechanical Pulping Conference, Minneapolis, June 2-5, 321-327.

Stationwala, M. I., Miles, K. B., and Karnis, A. (1993). "The effect of first-stage refining conditions on pulp properties and energy consumption,” J. Pulp Pap. Sci. 19(1), 1218.

Stationwala, M. I., Miles, K. B., and Karnis, A. (1994). "Effect of feed rate on refining," J. Pulp Pap. Sci. 20(8), J236-J240. 
Stationwala, M. I., Mathieu, J., and Karnis, A. (1996). "On the interaction of wood and mechanical pulping equipment, Part I: Fiber development and generation of fines," $J$. Pulp Pap. Sci. 22(5), J155-J159.

Strand, B. C., Falk, B., Mokvist, A., and Jackson, M. (1993). "The effect of production rate on specific energy consumption in high consistency chip refining," Proceedings of the International Mechanical Pulping Conference, Oslo, 143-151.

Strand, B. C. (1995). "The effect of refiner variation on pulp quality," 1995 International Mechanical Pulping Conference, Proceedings, Ottawa, 125-130.

Sui, O. S., Sanche, L., Mills, C., Smith, W., Smith, G., and Douglas, T. (1998). "Model based pulp quality control of TMP refiner," 1998 Pulping Conference, 295-309.

Tyrvainen, J. (1995). "The influence of wood properties on the quality of TMP made from Norway spruce (Picea abies) - wood from old-growth forests, first-thinnings, and sawmill chips," International Mechanical Pulping Conference, Proceedings, 2334.

Varhimo A. and Tuovinen O. (1999a). "Process Control," In: Papermaking Science and Technology, Kauko Leiviskä (ed.), Chapter 7, "Process control in mechanical pulping," Atlanta: Finnish Paper Engineer's Association and TAPPI.

Varhimo, A., and Tuovinen, O. (1999b). "Mechanical Pulping," In: Papermaking Science and Technology, Jan Sundholm (ed.), Chapter 5, "Raw materials", Atlanta: Finnish Paper Engineer's Association and TAPPI.

Varhimo, A., and Tuovinen, O. (1999c). "Mechanical Pulping," In: Papermaking Science and Technology, Jan Sundholm (ed.), Chapter 7, "Thermomechanical pulping”, Atlanta: Finnish Paper Engineer's Association and TAPPI.

Vuorio, P., and Bergqvist, P. (2001). "New refiner segments technology to optimize fibre quality and energy consumption of refiner mechanical pulp," 2001 International Mechanical Pulping Conference, Helsinki, Finland, 565-577.

Wood, J. R. (1996). "Chip quality effects in mechanical pulping - A selected review," 1996 TAPPI Pulping Conference, Proceedings, 491-497.

Wood, J. R. (2000). "Wood-induced variations in TMP quality - Their origins and control," TAPPI Pulping/ Process and Product Quality Conference, 259-267.

Wood, J. R. (2001). “Controlling wood-induced variation in TMP quality,” Tappi J. 84(6), 32-34.

Xu, Q., Qin, M., Ni, Y., Defo, M., Dalpke, B., and Sherson, G. (2011). "Predictions of wood density and module of elasticity of balsam fir (Abies balsamea) and black spruce (Picea Mariana) from near infrared spectral analyses," Can. J. Forest Res. 41(2), 352-358.

Article submitted: March 15, 2011; Peer review completed: May 28, 2011; Revised version received and accepted: June 6, 2011; Published: June 8, 2011. 